\title{
The GEEP Workshop: trace metal analyses
}

\author{
M. I. Abdullah, I. Steffenak \\ Department of Marine Zoology and Marine Chemistry, Biology Institute, University of Oslo, PO Box 1064, N-0316 Blindern, \\ Oslo 3, Norway
}

\begin{abstract}
As a counterpart to the biological analyses of the GEEP Workshop, chemical analyses of trace metals were carried out on sediments and on organs and tissues of fish (flounder), mussels and crabs, from the field sampling sites in Langesundfjord/Frierfjord and the experimental exposures in the Solbergstrand mesocosm facility. The field sites were not characterised by strong metal gradients, but both tissue and sediment analyses revealed differences between sites, particularly between the 'endpoints' of the anticipated contaminant gradient. In the mesocosm experiment, increasing copper dosing levels in the basin waters were closely matched by copper accumulation in mussel tissues and, to a lesser extent, crab tissues. Copper did not appear to accumulate in the fish livers nor in the top layers of the sediment used for the benthic community studies.
\end{abstract}

\section{INTRODUCTION}

While many trace metals in the marine environment are essential to the biota, some of these are also toxins at certain concentration levels. The ubiquitous trace metals, therefore, play a fundamental role in marine ecology, and knowledge of their abundance was an essential complement to the biological analyses of the workshop programme.

The toxicity of metals and the enzymatic and biochemical reactions induced by metals are complex processes, only brought about upon the assimilation of the metals through the various metabolic pathways. Consequently, the presence of metals in the tissues indicates possible associated metabolic interaction. Metals in water or sediment, on the other hand, define the exposure level.

For the GEEP Workshop, analyses were made of some metals known to be toxic and present as pollutants in the field sites and the mesocosm experiment. Particular emphasis was given to copper, which was a component of the contaminant dosing in the mesocosm exposures, but other metals analysed for all samples were zinc, iron, manganese, cadmium and lead; additionally, nickel and chromium were analysed for field sediments.

\section{MATERIAL}

Details of the collection of field material are given in Follum \& Moe (1988), and the design of the mesocosm experiment in Bakke et al. (1988). Metal analyses were performed on the following material.

(1) Sediment samples from Field sites $A$ to $G$ in Frierfjord/Langesundfjord (see Fig. 2 of Follum \& Moe 1988), collected at the same locations and times (22 Jan 1986) as the samples for benthic macrofaunal analysis. Sediment samples were submitted to one of us (I. S.) for metal analysis, having been collected and prepared by the Norwegian Institute for Water Research (NIVA), as follows. Three cores from each of the 7 field sites were collected with a Niemisto gravity corer; the upper two $1 \mathrm{~cm}$ sections were combined, dried, homogenised and sieved dry through a $63 \mu \mathrm{m}$ mesh. The smaller size fraction was analysed. This method of preparation is different from that used for the preparation of sediment samples from the mesocosm experiment.

(2) Sediment samples from the 4 mesocosm basins: $C_{\text {, }}$ L, $M$ and $H$ (respectively control, low, medium and high dosing of the basin water with a copper and diesel oil mixture). At the same time as the benthic macrofaunal samples were taken (21 Jul), 1 sediment sample was removed for metal analysis from 4 boxes in each basin, by hand-coring with $60 \mathrm{~mm}$ diameter plastic tubing. The top $1 \mathrm{~cm}$ was freeze-dried and homogenised.

(3) Samples of liver and kidney from 4 to 8 individual flounder, collected at each of the Field sites 1 to 4 in Langesundfjord (see Fig. 2 of Follum \& Moe 1988); for Site 4 only liver samples were analysed. Also analysed were liver samples from 4 individual flounder from each of the mesocosm basins, after an exposure period 
of about 16 wk. Chemical analysis was on a subset of the same individuals sampled for the biochemical determinations, collected on 11 to 14 August for the field sites and 18 to 21 August for the mesocosm basins Preparation for all biological material involved freezedrying and then homogenisation by grinding with agate pestle and mortar; an electric mill was used for very large samples.

(4) Two replicate pools of mussel whole tissues (10 ind per pool) were sampled from each of the Langesundfjord sites 1 to 4 . Though these were not the same individuals as used for any of the biological measures, they were selected at random from the common pool of mussels collected from each field site (on 11 to 14 August).

(5) Samples of mussel whole tissues from the mesocosm basins (usually only 1 pool of 10 ind per basin) were taken after $7 \mathrm{wk}$ exposure (on $13 \mathrm{Jun}$ ), with a further sample from each basin taken towards the end of the dosing period (4 Aug). Mussels restocked into al basins on 18 July (following mortality of the original stock of mussels in the high dose basin) were also sampled for metal content on 4 August. Samples of mussel digestive glands (mainly 1 pool of 30 ind. per basin) were also analysed for the mesocosm experiment, collection being concurrent with biological sampling during the period of the workshop.

(6) Finally, samples of whole tissues of crabs from the mesocosm experiment were taken on 4 August, after an exposure period of $12 \mathrm{wk}$ (2 replicate pools from each basin, each pool of 4 ind.).

Chemical analysis of nearly all of the above material was made available to participants by the end of the workshop period.

\section{METHODS}

Pyrex glassware was used throughout, after overnight washing with concentrated nitric acid. Acids were double distilled from a silica still. Metal-free distilled water was taken from a 2-stage silica distillation unit. Flame-AAS analysis was performed using a Varian Techtron AA-6, fitted with automatic gas control and background correction.

Sample digestion: sediments. About $300 \mathrm{mg}$ of the homogenised sediment was weighed into PTFE beakers, $10 \mathrm{ml}$ of concentrated nitric acid was added and the beakers were placed on a hot plate $\left(110^{\circ} \mathrm{C}\right)$ to extract acid soluble metals. After about $6 \mathrm{~h}$, the contents of the beakers were diluted to about $25 \mathrm{ml}$ and transferred to polyethylene centrifuge tubes. After centrifugation, the supernatant was transferred back to the PTFE beakers and evaporated to dryness. The residue was then redissolved in $1 \mathrm{ml}$ of $6 \mathrm{~N} \mathrm{HCl}$ and diluted to $25 \mathrm{ml}$.
Sample digestion: biological material. About $600 \mathrm{mg}$ of sample, or the whole tissue (80 to $150 \mathrm{mg}$ ), was weighed into conical flasks and $15 \mathrm{ml}$ of concentrated nitric acid added; the flasks were covered with glass bubbles and placed on a hot plate $\left(120^{\circ} \mathrm{C}\right)$ to reflux until complete mineralisation. When the extracts were clear and colourless, the flasks were uncovered and the solutions allowed to evaporate to dryness. Residues were then redissolved in $1 \mathrm{ml}$ of $6 \mathrm{~N} \mathrm{HCl}$ and made up to either 25 or $10 \mathrm{ml}$ depending on sample weight. Blanks were run concurrently with the sample mineralisation.

Analysis. Working standards of the elements, covering the concentration range anticipated in the samples, were prepared in $0.1 \mathrm{~N} \mathrm{HCl}$. The instrumental settings for the Varian AA- 6 were those recommended and the flame stoichiometry was adjusted for maximum absorption. The instrumental sensitivity was adjusted using the variable nebuliser and by altering the flame light path, to allow for both low and high levels of metals to be quantified. Calibration was by either linear or polynomial regression.

\section{RESULTS AND DISCUSSION}

Results are given in Appendix 1 of this volume, Tables 12 to 18 . Blanks for $\mathrm{Cu}, \mathrm{Mn}, \mathrm{Cd}$ and $\mathrm{Pb}$ were below the analytical detection limit. Blanks for $\mathrm{Zn}$ and Fe were detectable; however, readings were less than $1 \%$ of the sample values and were taken into account in the computation of results

The 3 sediment cores from each field site and the 4 cores from each mesocosm basin showed considerable variation in metal content (Appendix 1, Tables 12 and 13). While some of this variation might be explained by spatial inhomogeneity within a field site, perturbation of the sediments during transfer or sampling may have contributed an additional component. Such perturbation would produce variation most evidently in the upper few centimetres where large gradients in metal concentration are often found. Variation in $\mathrm{Mn}$ content of replicate sediment cores from the field sites was particularly high - as much as 5 fold at some sites. There is no obvious explanation for this, though it is possible that the variation may be an artifact of dry size fractionation of unconsolidated sediment; usually such sediments are fractionated wet. Metal concentrations for the biological material showed no obvious anomalies, in terms of variation within a site/experimental condition; considerable variation between animals is to be expected.

Sediments from benthic sampling sites in Frierfjord/ Langesundfjord showed significant differences in content of most metals with, in general, Site A having the 
lowest values and Site $G$ the highest (Appendix 1 , Table 12). Between these 2 end points, the pattern of the contaminant gradient differed for different metals; Fig. 1 displays the gradients for $\mathrm{Pb}$ and $\mathrm{Cd}$ across the field sites. Plots for some of the other metals can be found in Appendix 1. Gradients for $\mathrm{Cu}$ and $\mathrm{Zn}$ are broadly similar to that for $\mathrm{Pb}$ whilst the patterns for $\mathrm{Fe}$, $\mathrm{Mn}, \mathrm{Cr}$ and $\mathrm{Ni}$ are somewhat different, being characterised by lower values at Site E. The complete set of metal data was subjected to multivariate statistical analysis (PCA - Principal Component Analysis, Seber 1984) by Gray et al. (1988), and the resulting PCA plot is given in Fig. 14a of that paper; it clearly demonstrates the placing of Sites $A$ and $G$ at opposite extremes of the pollution gradient (represented by the first PC axis), and the separation (on the second PC axis) of Site E from the other intermediately contaminated sites. It is clear, therefore, that the metal gradient
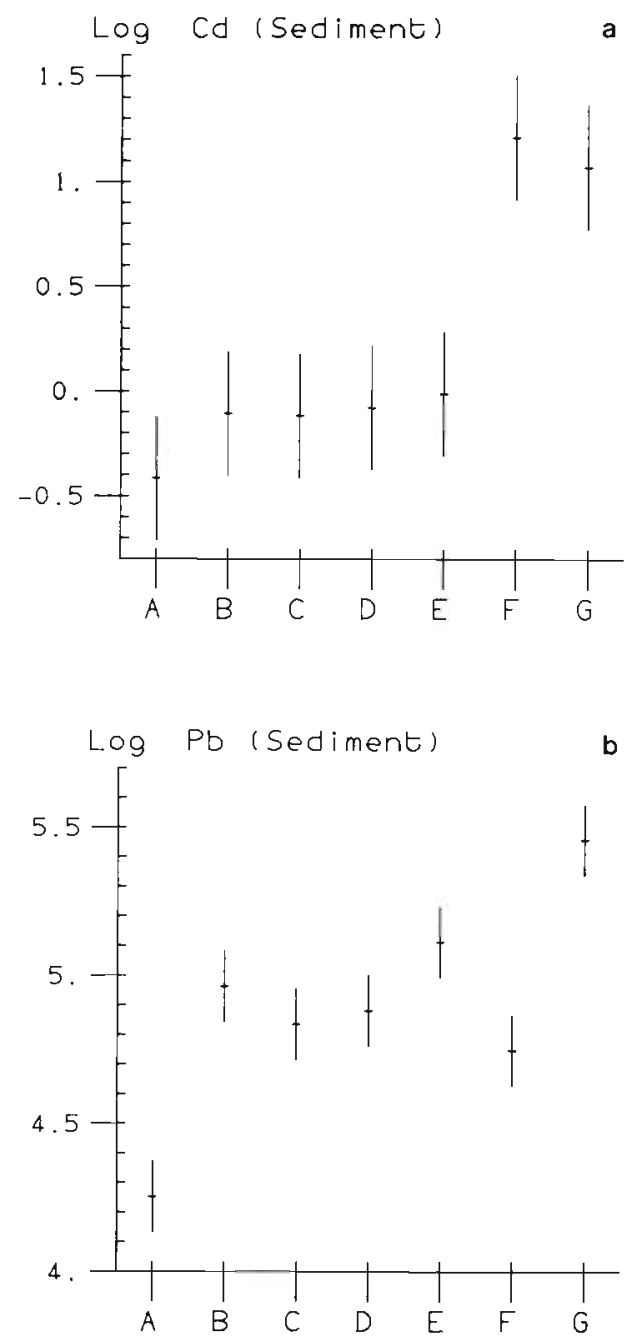

Fig. 1. Concentrations ( $\mu \mathrm{g} \mathrm{g}^{-1}$ dry wt) of (a) $\mathrm{Cd}$ and (b) $\mathrm{Pb}$ in the top $2 \mathrm{~cm}$ of sediments (size fraction $<63 \mu \mathrm{m}$ ) from Benthic sampling sites $\mathrm{A}$ to $\mathrm{G}$ in Frierfjord/Langesundfjord (mean \pm $95 \%$ CI of $\log _{e}$-transformed data, $n=3$ ) does not arise solely from simple linear dispersion from a single pollutant source at the head of Frierfjord, but reflects both the complex hydrography of such fjordic environments (Follum \& Moe 1988) and the possibility of additional pollutant sources. However, it must be pointed out that the field sediment data are for the $<63 \mu \mathrm{m}$ particle fraction obtained by sieving the dried sediment. Such data can often disguise the real metal content of the sediments, particularly when the abundance of the $>63 \mu \mathrm{m}$ fraction is not specified.

For the sediments in the mesocosm experiment (Appendix 1, Table 13), 1-way analysis of variance demonstrates no significant difference in $\mathrm{Cu}$ content of the top $1 \mathrm{~cm}$ of sediments between the various basins, in spite of the differing levels of $\mathrm{Cu}$-dosing in the input water (nominal water concentrations of $0.8,5$ and $20 \mu \mathrm{g}$ $\mathrm{I}^{-1}$ for the $\mathrm{L}, \mathrm{M}$ and $\mathrm{H}$ basins respectively; Bakke et al. 1988). This failure of the sediments to reflect differ-
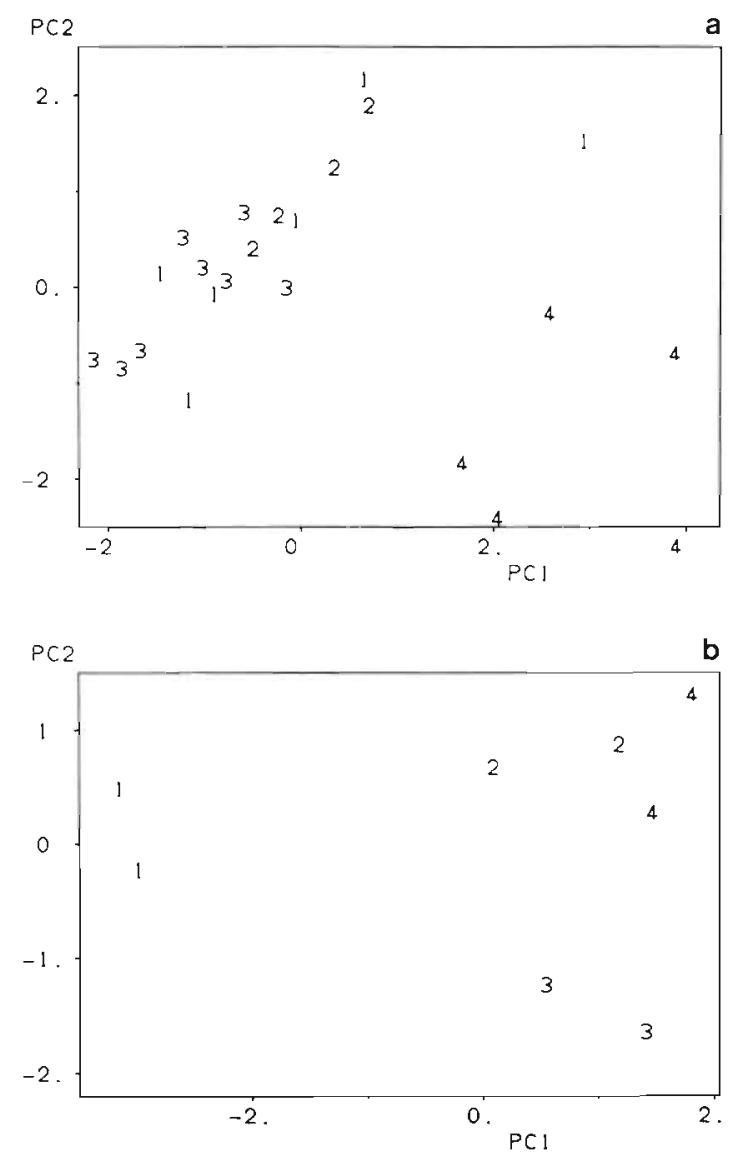

Fig. 2. Principal Component Analyses of $\mathrm{Cu}, \mathrm{Zn}, \mathrm{Pb}, \mathrm{Cd}, \mathrm{Mn}$ and Fe concentrations, at Field sites 1 to 4 in Langesundfjord. (a) Platichthys flesus liver $\left(n=4 \text { to } 8 \text { ind. site }{ }^{-1}\right)_{\text {i }}$ (b) Mytilus edulis, whole tissues $(n=2$ pools); data from Appendix 1 , Tables 14 and 16. Metal levels were $\log _{\mathrm{e}}$-transformed and normalised prior to PCA. The first $2 \mathrm{PC}$ axes account for about 70 and $80 \%$, respectively, of the total variability in metal data 


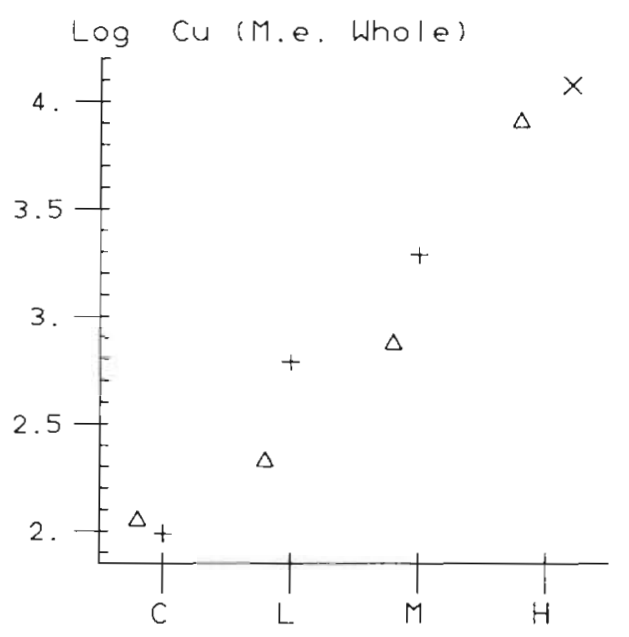

Fig. 3. Mytilus edulis. $\mathrm{Cu}$ concentrations $\left(\mu \mathrm{g} \mathrm{g}^{-1} \mathrm{dry}\right.$ wt, plotted on a $\log _{e}$ scale) in whole tissues of mussels from the mesocosm basins (values from a single pool of 10 ind.). Mussels stocked on 24 April: $(\Delta) 7$ wk exposure; (+) $15 \mathrm{wk}$ exposure; mussels stocked on 18 July: $(x) 18 \mathrm{~d}$ exposure

ences in water concentration should not be unexpected, in view of the relatively short time-scale of exposure (ca $12 \mathrm{wk}$ ).

Metal concentrations for liver and kidney samples of flounder from the field sites (Appendix 1, Table 14) show some significant differences, for example in the elevated zinc levels for liver samples from Site 4. Fig. 2a shows the PCA plot resulting from analysis of fish liver concentrations at Field sites 1 to 4 . The first PC axis is a roughly equally-weighted total of (normalised) levels of all metals, and therefore represents a gradient of increasing metal contamination. The higher impact at Site 4 is apparent, though the other sites cannot be significantly differentiated. Metal concentrations in the livers of individual fish from the mesocosm experiment (Appendix 12, Table 15) are sufficiently variable within treatments to mask any differences between treatments. In particular, $\mathrm{Cu}$ concentrations do not appear to have increased in response to $\mathrm{Cu}$-dosing. Further discussion of metal analyses for the fish samples can be found in Overnell \& Abdullah (1988).

In contrast to the very clear gradient of PAH contamination in mussel tissue across Field sites 1 to 4 (Klungsøyr et al. 1988), a gradient of metal contamination is much less apparent (Appendix 1, Table 16). Fig. 2b shows the result of a PCA on these data; the first PC axis again represents a gradient of increasing overail metal contamination and Site 1 clearly stands out as significantly less contaminated. (Site 3 is distinguished from the other 2 sites, on the second PC axis, because of its higher $\mathrm{Fe}$ and Iower $\mathrm{Mn}$ values)

The mussels in the mesocosm experiment, in contrast to the flounder, did take up the dosed $\mathrm{Cu}$ into the tissues, and did so in a very uniform manner in line with the levels of dosing in the water (Fig. 3 and Appendix 1, Table 17). The pattern for crab whole tissues (Appendix 1, Table 18) was less clear but there were significantly higher $\mathrm{Cu}$ concentrations for the $\mathrm{M}$ and $\mathrm{H}$ dosed animals than for those in the $\mathrm{C}$ and L basins.

Further discussion of metal concentrations in mussels from the mesocosm experiment can be found in Widdows \& Johnson (1988), and Viarengo et al. (1988) present additional analyses of metal levels in the digestive glands of mussels from both field and mesocosm studies.

Acknowledgements. We acknowledge the work of several people in sample collection and (for field sediments) sample preparation, in particular Odd-Arne Follum, Kjell Moe and staff of the Norwegian Institute for Water Research (NIVA). The statistical analysis was performed by Bob Clarke and Martin Carr.

\section{LITERATURE CITED}

Bakke, T., Follum, O. A, Moe, K. A, Sørensen, K. (1988). The GEEP Workshop: mesocosm exposures. Mar. Ecol. Prog Ser 46: 13-18

Follum, O. A., Moe, K. A. (1988). The GEEP Workshop: field sampling. Mar. Ecol. Prog. Ser. 46: 7-12

Gray, J. S., Aschan, M., Carr, M. R., Clarke, K. R., Green, R. H., Pearson, T H. Rosenberg R., Warwick, R. M. (1988). Analysis of community attributes of the benthic macrofauna of Frierfjord/Langesundfjord and in a mesocosm experiment. Mar Ecol. Prog. Ser. 46: 151-165

Klungsøyr, J., Wilhelmsen, S., Westrheim, K., Saetvedt, E., Palmork, K. H. (1988). The GEEP Workshop: organic chemical analyses. Mar Ecol. Prog. Ser. 46: 19-26

Overnell, J., Abdullah, M. (1988). Metallothionein and metal levels in flounder Platichthys flesus from four field sites and in flounder dosed with water-borne copper. Mar. Ecol. Prog. Ser. 46: 71-74

Seber, G. A. F. (1984). Multivariate observations. Wiley, New York

Viarengo, A., Mancinelli, G., Martino, G., Pertica, M., Canesi, L., Mazzucotelli, A. (1988). Integrated celluiar stress indices in trace metal contamination: critical evaluation in a field study. Mar Ecol. Prog. Ser 46: 65-70

Widdows, J., Johnson, D. (1988). Physiological energetics of Mytilus edulis: Scope for Growth. Mar. Ecol. Prog. Ser. 46: $113-121$ 